\title{
L'extraction du sel gemme dans un village de haute Birmanie
}

François Robinne

\section{(2) OpenEdition \\ 1 Journals}

Édition électronique

URL : https://journals.openedition.org/tc/843

DOI : $10.4000 /$ tc. 843

ISSN : 1952-420X

Éditeur

Éditions de l'EHESS

Édition imprimée

Date de publication : 1 mars 1988

ISSN : 0248-6016

Référence électronique

François Robinne, "L'extraction du sel gemme dans un village de haute Birmanie ", Techniques \& Culture [En ligne], $10 \mid$ 1988, mis en ligne le 23 janvier 2006, consulté le 29 septembre 2022. URL: http://journals.openedition.org/tc/843; DOI : https://doi.org/10.4000/tc.843

Ce document a été généré automatiquement le 29 septembre 2022.

Tous droits réservés 


\title{
L'extraction du sel gemme dans un village de haute Birmanie
}

\author{
François Robinne
}

